\title{
GENERAL CHARACTERISTICS OF THEMATIC VILLAGES IN POLAND
}

\section{Anna KŁOCZKO-GAJEWSKA}

\author{
Warsaw University of Life Sciences - SGGW, Faculty of Economic Sciences, Warsaw, Poland
}

\begin{abstract}
In recent years, rural areas in Poland have undergone significant changes. Agricultural production is getting more and more specialized. Consequently, bonds between farmers within the same village weaken, while farmers get to socialize more with those with the same specialization, no matter the distance. As a result, social life in some of the villages declines. Simultaneously, small- and medium-scale farmers, who cannot compete with large farms, have been looking for additional, off-farm sources of income. One of the ways to revive feeling of a common goal and cooperation and at the same time to get additional income is creating a thematic village, whose development is focused on a certain topic (local food, craft, history, or some other ideas). It seems that this idea gives a chance for strengthening the social activeness and self-confidence of the villagers, and in some cases also for getting additional income.
\end{abstract}

Keywords: villages, Poland, thematic villages operating

\section{Introduction}

The number of farms in Poland is significantly higher than in other EU countries of similar or bigger size. Small farms, usually of semi-subsistence or subsistence character, dominate (about $50 \%$ of farms are smaller than $5 \mathrm{ha}$, at the same time, average size of a farm above $50 \mathrm{ha}$ is $179 \mathrm{ha}$ ) (Wąs, 2013). Moreover, further polarisation is observed; farms sized between 5 ha and 15 ha tend to either grow and focus on market production, or get smaller and produce mostly for the needs of the family (Ziętara, 2008). The number of people employed in farming declines, similarly as in other new EU member states (Kłoczko-Gajewska, 2010), and the decline of jobs in agriculture is not compensated by equivalent growth of workplaces in services and manufacturing in rural areas (Wilkin, 2011).

Present global trends of specialisation and intensification of agricultural production have an influence both on incomes and on social life of the inhabitants of rural areas in Poland. Due to mechanisation, the need for neighbour help declines, and because of specialisation, there are less common topics to discuss. As a consequence, village citizens are no longer a unity in the way of living, work, and interests. It happens that farmers socialize more with those with the same specialization, no matter the distance than with their neighbours, which was not common a couple of years ago (Perepeczko, 2009).

It is estimated that in the future, many inhabitants of peripheral rural areas will not be able to make a living from farming, which can lead to deepening of socio-economic problems. However, there is a chance to overcome some of these issues through strengthening multifunctional development of rural areas, with emphasis on protecting cultural and environmental diversity of local communities (Wilkin, 2005). Putting more emphasis on cultural issues is a chance for development, as food products coming from farms deliver not only certain amount of callories and vitamins, but they can transfer tradition, uniqueness, or emotions (Błąd, 2010).

Creating a uniqe identity leads to higher involvement of people engaged in actions of a company, but pretty well also a country, a region or a town. Clear perception of certain entity outside it (a brand name) can affect its development (Kłoczko, 2001). This way of thinking is visible in the idea of thematic villages, where inhabitants jointly decide on a topic and prepare unique tourist attractions based on local cultural, natural, and social heritage.
Such brand name or identity of a village can lead to better self-perception and higher self-confidence of people engaged in the project, higher evaluation of their own village, and creation of additional sources of income (Idziak, 2011; (zapiewska, 2012). We can state that thematic villages account a system of doing old things in new ways where farming is an old thing, but a farm considerating e.g. ecological principles and/or open to the public and active in informal education represents a new way (Horská, 2013)

Thematic villages in Poland have been created only during recent few years. This paper ${ }^{1}$ is supposed to deliver general characteristics of this newly emerging phenomenon.

\section{Material and methods}

The research begun with the initial list of 55 thematic villages, found on a website of a specialist engaged in promotion of this idea. Searching through the internet and using the snowball method, that is asking every respondent if they have heard of any other thematic vilages, the list was extended to 106 names, which probably cover most of the thematic villages in Poland ${ }^{2}$.

If the phone number to the contact person could be found on the Internet, this person was called directly. In other cases, the local administration NUTS 5 office was called in order to find the number. If it came out that this village indeed was operating as a thematic village, an interview with a list of open questions was carried out (usually with the most engaged person, that is the leader, but sometimes with village administrator, animator from an NGO helping this particular thematic village, or a worker of a local NUTS 5 office).

At the moment of the interview (July 2013), there were 78 villages operating as thematic villages, 14 that have tried it but abandoned the idea, 3 that have suspended their activities for some reasons, 2 from the list that did not fulfill the criteria of thematic village, 7 in the making, and 5 that could not be contacted (nobody answered the phone during several days,

1 Some of the results presented in this paper were published in my paper Thematic villages in Poland - a brief overview, Conference proceedings, 3-5 0ctober 2013, Szent Istvan University, Godollo, Hungary, pp. 171-177.

2 The list was consulted with Waclaw Idziak, who organizes trainings for thematic villages. 


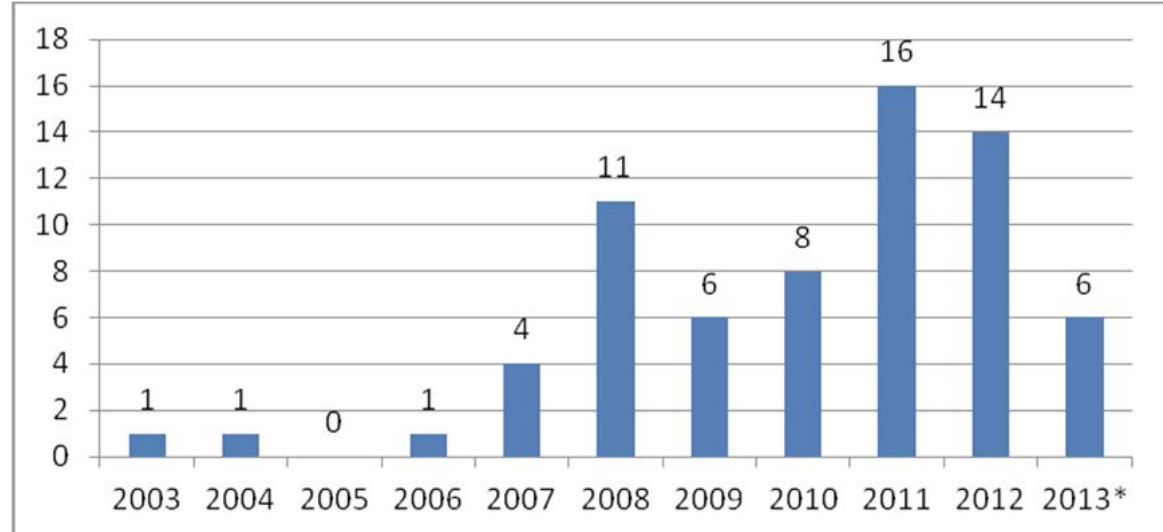

Figure 1 Newly emerging ${ }^{* *}$ thematic villages in Poland (only those that are still active in 2013) (*first half of the year)

Source: own editing, 2013

**All cases of active villages where the date of emergence was known - that is all the interviewed and few additional ones, not interviewed

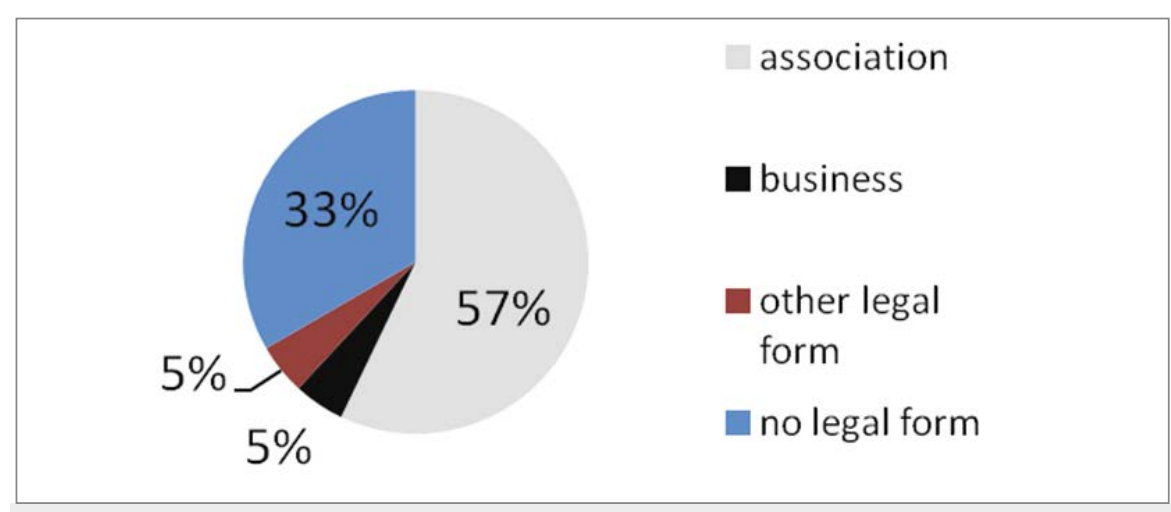

Figure 2 Legal form of thematic villages operating in Poland in 2013

Source: own editing, 2013

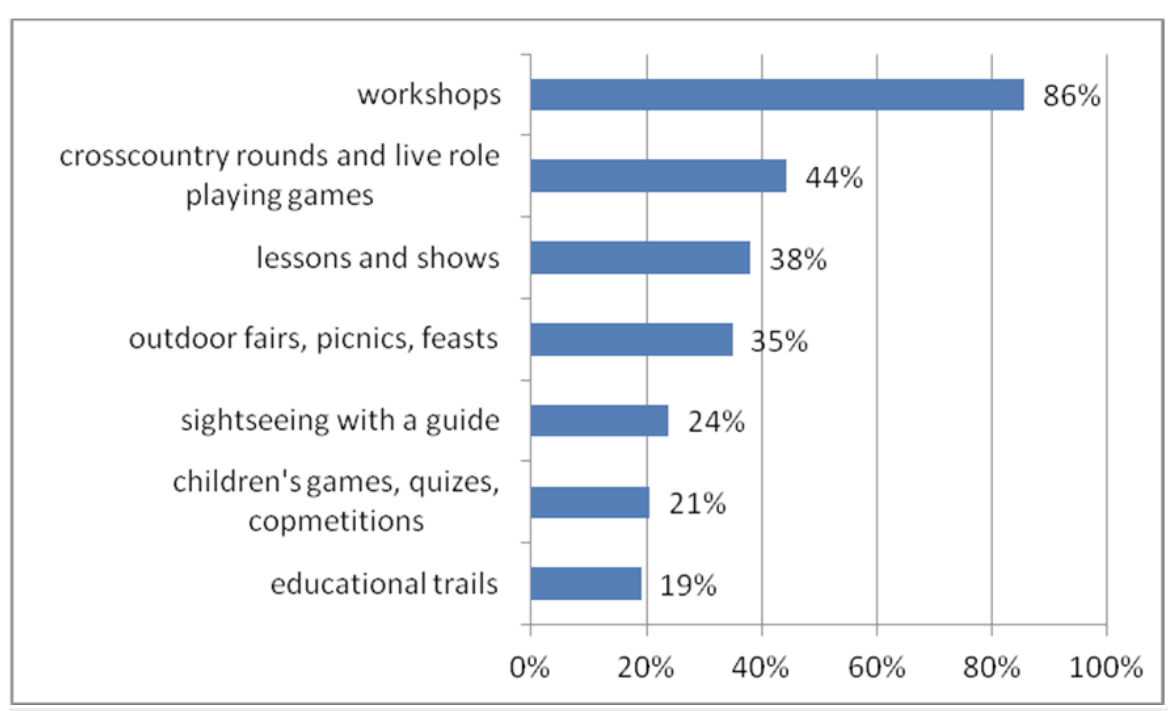

Figure 3 Main tourist offer of thematic villages in Poland in 2013

Source: own editing, 2013 at different times of the day ${ }^{3}$ ). The author of the paper managed to carry out 63 interviews with people engaged in these villages. If not stated otherwise, all the analyses below refer only to these 63 interviewed villages.

The research was of an explorative character, thus the main aim was to describe current state of thematic vilages in Poland.

\section{Results and discussion}

The interviewed villages are of various sizes, beginning from 50 to about 2,500 citizens, situated in 12 out of 16 NUTS 2 regions in Poland

First thematic villages started to operate in Poland in 2003, and significant rise in the number of newly emerging villages could be observed since 2007, with a peak in 2011 (Figure 1). It took between several weeks to few years since the first idea of creating a thematic village emerged until it was ready to operate (in most of the cases, this readiness was measured as being ready for inviting tourists).

The topics for the development were chosen in a variety of ways. Four of the villages have chosen their topics based on the village name (angels, adventures, butterflies, apples) and 12 resulted from strong local traditions, where the choice was really obvious to the citizens usually related to an occupation (pottery, beekeeping), but also remains of ethnic minority. Brainstorming sessions, including SWOT analyses of the villages and their surroundings resulted in the development of 32 topics, and 15 were chosen for other reasons (books, films, private interests of the leader, etc.).

Most of the thematic villages are registered as associations (Figure 2). It is worth mentioning that in 9 of the cases, there were associations already existing, aiming at the development of the village; in these cases creation of a thematic village was only an idea to set a direction for the activeness of the members. About $1 / 3$ of thematic villages have no legal form, but some of them are in close contact with other organisations that help them, for example in applying for external funds (Farmers' Circles, Commune Cultural Centres, other local associations). Among interviewed ones, there were 3 private businesses and 3 of other legal form.

In two of the interviewed villages, there is no offer for tourists, because they want to concentrate only on development of the village

3 It is possible though that at least some of them do actively operate, because some of the interviewed leaders were really difficult to access. 
itself. The remaining ones have some offer for tourists: 31 only for organised groups, and 30 both for groups and individuals, and they quite often focus on school and youth camps. Most commonly offered services are presented in Figure 3.

Usually, the visitors can participate in workshops of different kinds: preparation of traditional food (making butter and cottage cheese manually, baking bread and various cakes), crafts (pottery, making souvenirs of various natural materials such as straw, stones, bones, etc), old-fashioned sports (bows, cannon shooting), and many others. Some of the workshops are strongly connected with the main development topic, while in some the connection is hardly visible. Almost half of the villages offer cross-country rounds or live role playing games; in some of them there is a widely advertised annual event where many citizens dress up for strange creatures (witches, dwarves, angels, hobbits, etc).

Lessons and shows that can be found in almost $40 \%$ of the villages take a variety of forms, beginning from a show of a real blacksmith, through visiting two cowsheds: a traditional one and a very modern one, through walking educational trails, finishing with multimedia lessons about nature. Outdoor fairs, picnics and feasts for tourists are offered in a similar number of villages - either in certain days of the year or when ordered by a large group. There is also a number of villages that traditionally organise such events only for their citizens (and neighbour villages). In some of the villages, the range of offered services is really impressing, while in the other ones, there is a focus on a certain type of activities or the offer is in the making. Most of the villages have some plans for the future, beginning form social issues (to make some young people more engaged), through evolutionary widening the offer, to serious investment plans.

It is difficult to talk about the long-term consequences of creating thematic villages, as most of them have been operating for only few years. Nevertheless, it is worth making an attempt and briefly sketching first changes in the villages during that time. It should be noted, however, that we are talking about changes since the thematic villages operate; at this stage of the research, it is not possible to fully distinguish which of the changes are really a result of choosing the topic for development, and in which the changes result from other factors.

The respondents asked to enumerate changes in the villages in $81 \%$ of the cases said that the look of their villages have changed (Figure 4). This issue will be addressed in more details in the next figure. About $3 / 4$ of the respondents have

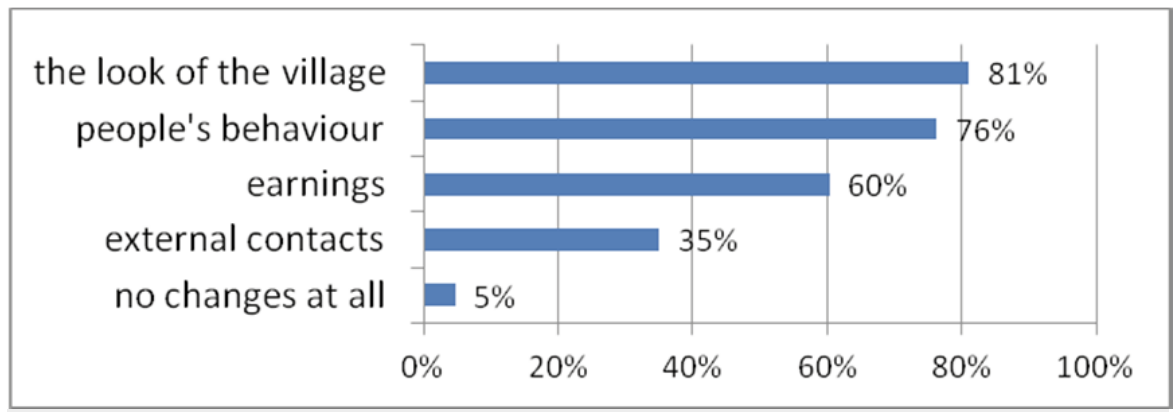

Figure 4 Declared main changes in the villages since the thematic villages operate in Poland, 2013 Source: own editing, 2013

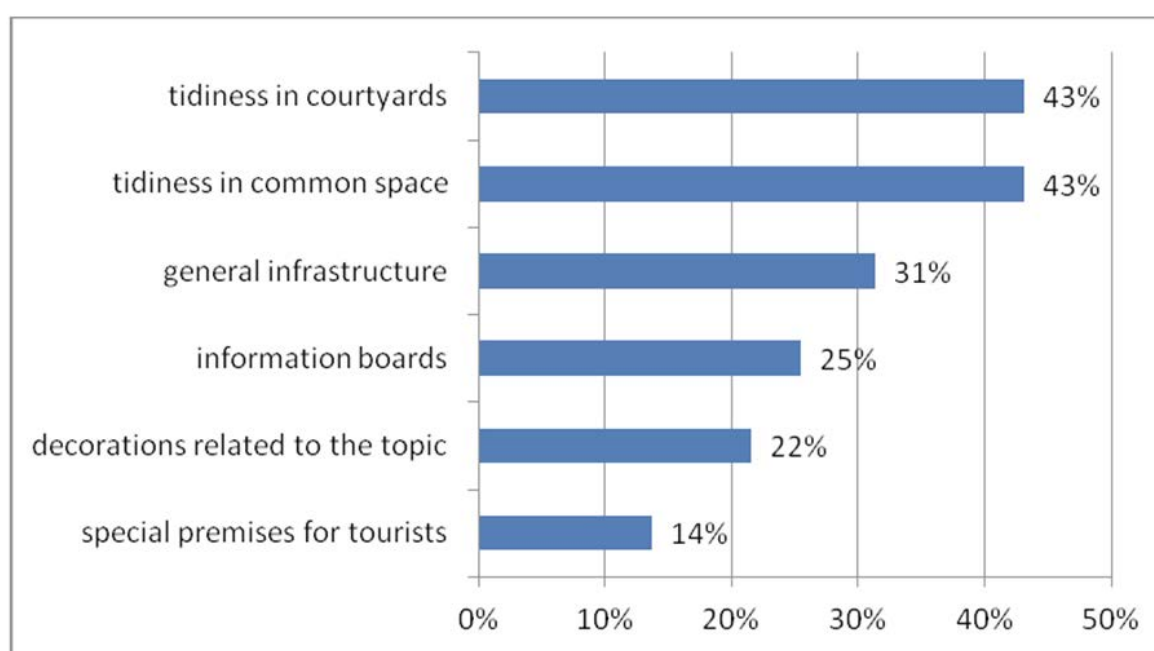

Figure 5 Declared main changes in the look of the village since the thematic village operates in Poland, 2013

Source: own editing, 2013

seen some changes in the villagers' behaviour mostly they became more active and self-assured, engaged in common activities, and/or proud of their village, but in few cases, the creation of a thematic village ended up in a conflict between the supporters of the idea and those against it.

The third most common outcome were earnings - mostly small and seasonal, sometimes just enough to cover the costs, but in 3 of the villages, there were people that found jobs (the most successful has created 200 permanent jobs, two others - 18 and 60 seasonal workplaces). In some of the cases, the money was spent on common goals, such as repainting the village common hall or organizing excursions for the villagers, and in some, the money was received directly by the people engaged. Above $1 / 3$ of the villages had more external contacts: with other thematic villages, other associations (for example local action groups), and in few cases also with universities and scientific institutions (those needing specialist consultancy, such as medieval village, dinosaur park or specialist herb cosmetics). Three of the respondents haven't seen any changes in the village, even though all three of the villages have been operating for at least two years.

Coming back to the changes in the look of the villages (Figure 5), it usually meant rise in care for the tidiness of both common space in the village and private courtyards (43\%). In almost $1 / 3$ of the villages, general village infrastructure was developed, among others playgrounds for children were prepared, common meeting rooms renovated, and some benches were bought. In $1 / 4$ of interviewed villages, information boards were prepared, and almost the same amount of villages prepared decorations related to their themes; these were usually welcome boards, house numbers painted in a special way, and pictures made of flowers. More advanced premises for tourists were built in $14 \%$ of the villages, to mention only a blacksmith shop, a thatched hut, and in one case a large dinosaur park.

It is important to remember, though, that as many as 14 villages have tried to operate in this manner, but gave up for some reasons. In these cases probably long-term changes cannot be observed, or even worse - people could get disinclined if they failed in their efforts. 
In order to finance their investments, most of the villages (59 out of 63) have applied for external financing, and almost all were given the money. The sums varied significantly, from very small amounts of money for painting the community center, to large amounts of money for construction of new buildings. The sources came from the EU and governmental projects, funds from local and regional authorities, NGOs, and private sponsors. For formal reasons, thematic villages having legal form found it easier to apply for official funds, but remaining ones also found their way: they usually applied through the nearest befriended local association.

When asked, most of the respondents declared further plans of developing the villages (only 5 villages had no plans for the future). More than $40 \%$ said that they wanted to widen their offer for tourists. Almost $20 \%$ intended to develop village infrastructure, the same amount planned more serious investments. Among less popular ideas one can find: preparing places to sleep, getting more villagers involved, using new forms of promotion (internet sites, leaflets), more decorations, and the like.

\section{Conclusions}

The interest in organising thematic villages seems to be growing in Poland during recent 10 years. They usually take form of associations or informal groups, often cooperating with other local organisations. Their offer is quite diversified, focusing mostly on combining active education with entertainment. According to the respondents, there are some visible changes in the look of the villages, social activeness of the inhabitants, and their pride of the village, which supports the theoretical goals of creating thematic villages. As for the additional sources of income, these are usually very small, but they may grow in time, when the offer is more widely known. Most of them have plans for future development, which support the thesis of activating the inhabitants. However, it should be noted that not all the villages develop thanks to this idea, thus we can conclude that it gives a chance, but no guarantee. The problem needs further research, especially after longer time since the villages were established.

\section{References}

BŁĄD, M. 2010. Kulturowe funkcje wsi i rolnictwa. In: Wilkin (Ed.): Wielofunkcyjność rolnictwa. Kierunki badań, podstawy metodologiczne i implikacje praktyczne. Warszawa : IRWIR PAN, 2010, p. 165-180

CZAPIEWSKA, G. 2012. Wioski tematyczne sposobem na aktywizację gospodarczą i społeczną regionu. Studia i Materiały. In: Miscellanea Oeconomicae, vol. 1, 2012.

HORSKÁ, E. 2013. Sustainability and Local Solutions: Managerial and Marketing Implications in Agrifood Business. In: Elena Horská - Tlektes I. Yespolov: Sustainability in Business and Society: Global Challenges - Local Solutions. Krakow : Episteme, 2013, p. 111-132.

IDZIAK, W. 2011. Turystyka społeczna - inspiracje dla turystyki wiejskiej. In: Folia Pomeranae Universitatis Technologiae Stetinensis - Oeconomica, vol. 288, 2011, no. 64, p. 9-18.

KŁOCZKO, M. Nadążać z tożsamością - z Augustowa do Brukseli. In: Boruc (ed.): Tożsamość rynkowa. Atrybut konkurencyjnego państwa. Warszawa : Instytut Marki Polskiej, 2001, p. 77-85.

KŁOCZKO-GAJEWSKA, A. 2012. Rola gospodarki rolnej i przemysłu spożywczego w nowoprzyjętych krajach Unii Europejskiej. In: Ekonomika i Organizacja Gospodarki Żywnościowej, vol. 98, 2012, p. 79-90.

PEREPECZKO, B. 2009. Zmiany ilościowe i jakościowe w rolnictwie a lokalny kapitał społeczny. In Psyk-Piotrowska (ed.): Kapitał społeczny. Partycypacja obywatelska. Rozwój lokalny. Łódź: Wydawnictwo UŁ, 2009, p. 80-89.

WILKIN, J. 2011. Wielofunkcyjność wsi i rolnictwa a rozwój zrównoważony. In: Wieś i rolnictwo, vol. 153, 2011, no. 4, p. 27-39.

WĄS, A. 2013. Modelowanie przemian strukturalnych polskiego rolnictwa. Warszawa : SGGW, 2013.

WILKIN, J. 2005. 0 potrzebie i założeniach długookresowej wizji rozwoju wsi w Polsce. In Zawalińska (ed.): Rozwój obszaró wiejskich. Doświadczenia krajów europejskich. Warszawa : IRWIR PAN, 2005, p. 45-56.

ZIĘTARA, W. 2008. Uwagi o przyszłości polskich gospodarstw. In: Wyzwania przed obszarami wiejskimi i rolnictwem w perspektywie lat 2014-2020. Warszawa : IRWIR PAN, 2008, p. 215-217.

\section{Contact address:}

Dr Anna Kłoczko-Gajewska, Assistant professor, Warsaw University of Life Sciences - SGGW, Faculty of Economic Sciences, Nowoursynowska 166, 02767 Warsaw, Poland, e-mail: anna_kloczko_gajewska@sggw.pl 